\title{
Assessing qualitative long-term volcanic hazards at Lanzarote Island (Canary Islands)
}

\author{
Laura Becerril $^{1}$, Joan Martí ${ }^{1, a}$, Stefania Bartolini ${ }^{1}$, and Adelina Geyer ${ }^{1}$ \\ ${ }^{1}$ Institute of Earth Sciences Jaume Almera, ICTJA-CSIC, Lluís Solé i Sabarís s/n, 08028 Barcelona, Spain \\ anow at: the Institut des Sciences de la Terre d'Orléans (ISTO, CNRS), Université d'Orléans, Campus Géosciences, \\ 1A rue de la Férolerie, 45071, Orléans CEDEX 2, France \\ Correspondence to: Laura Becerril (laurabcar@gmail.com)
}

Received: 2 January 2017 - Discussion started: 16 January 2017

Revised: 11 May 2017 - Accepted: 15 May 2017 - Published: 11 July 2017

\begin{abstract}
Conducting long-term hazard assessment in active volcanic areas is of primary importance for land-use planning and defining emergency plans able to be applied in case of a crisis. A definition of scenario hazard maps helps to mitigate the consequences of future eruptions by anticipating the events that may occur. Lanzarote is an active volcanic island that has hosted the largest ( $>1.5 \mathrm{~km}^{3}$ DRE) and longest (6 years) eruption, the Timanfaya eruption (1730-1736), on the Canary Islands in historical times (last 600 years). This eruption brought severe economic losses and forced local people to migrate. In spite of all these facts, no comprehensive hazard assessment or hazard maps have been developed for the island. In this work, we present an integrated longterm volcanic hazard evaluation using a systematic methodology that includes spatial analysis and simulations of the most probable eruptive scenarios.
\end{abstract}

\section{Introduction}

Active volcanic areas require conducting long-term hazard assessments in order to ensure rational land planning and to expand precise emergency plans that can be applied in case of a crisis. Long-term hazard assessment is important for identifying the main aspects related to volcanic hazards, such as the extension, the magnitude and the potential hazard impact zones in an area, which should be known by local population and potential visitors, especially when these may potentially affect tourist destinations. Unfortunately, this is not the case for many active volcanic areas around the world, particularly in places with a lower eruption frequency, thus causing local societies to rapidly forget about past events. Also, even when the impact of past eruptions has not been very significant causing no serious damage to human life or properties - they might be a socioeconomic disaster due to urban sprawl and the vulnerability of exposed elements.

This is, for example, the case of the Canary Islands, where, despite 15 eruptions in historical times (last 600 years), volcanic hazard assessment is still a pending task for most of the islands. This volcanic archipelago, which includes four national parks, is one of the most important tourist destinations in Europe. Tourism has had a considerable economic impact on this region, which has experienced a tremendous demographic expansion in the last 50 years (ca. 1 million inhabitants in 1970 and more than 2 million people in 2016; http://www.gobiernodecanarias.org/istac/). This demographic growth, not always well planned and without considering potential natural hazards, may now interfere with the effective management of future volcanic crisis. The last eruption, which occurred in El Hierro (Fig. 1 inset) in 20112012, is a good example of the implications of not having conducted a previous hazard assessment. Despite having an emergency plan that was correctly applied during the crisis, the occurrence of a submarine eruption was not considered as a probable scenario, although afterwards it was proven to be one of the most probable scenarios (Becerril et al., 2013, 2014, 2015).

Here, we concentrate our attention on Lanzarote (Fig. 1), the easternmost island of the Canary archipelago. It had the largest historical eruption of the Canaries (Timanfaya, 1730-1736) and one of the largest in Europe. Lanzarote, declared a biosphere reserve by UNESCO (1993, 


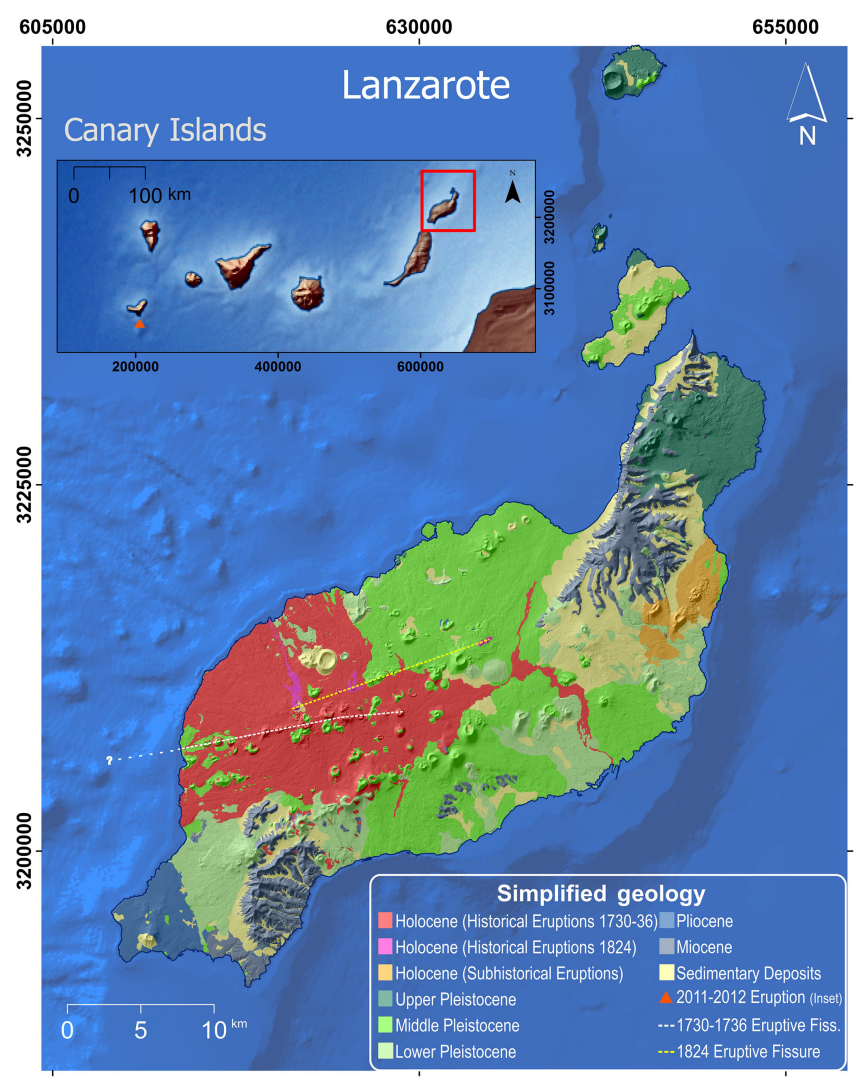

Figure 1. Simplified geological map of Lanzarote Island. The top left inset displays the location of Lanzarote within the Canary Archipelago. Original geological map can be found in http://info. igme.es/cartografiadigital/geologica/Geode.aspx.

http://www.lanzarotebiosfera.org/) and Global Geopark (2015, http://www.geoparquelanzarote.org/), is an important tourist destination with 12 natural protected areas (http: //www.gobiernodecanarias.org/cmayot/espaciosnaturales/) and a national park (1974, http://www.gobiernodecanarias. org/parquesnacionalesdecanarias/es/Timanfaya/) that receives nearly 1.5 million visitors per year. As in the rest of the Canary Islands, local economy is tourism based and volcanism is regarded as an attraction and not as a potential problem for both local population and visitors.

During the last 2 decades, several attempts have been made to analyse volcanic hazard in Lanzarote. The first published works are by Felpeto (2002) and Felpeto et al. (2001, 2007) who presented a new methodology for the evaluation of the lava flow hazard on Lanzarote. However, these studies only focused on simulating lava flows related to a Timanfayatype eruption (see the geological setting description to obtain more information about this eruption) without performing a general susceptibility analysis or a lava flow map for the whole island. Bartolini et al. (2013) presented the first susceptibility map of Lanzarote as an example of application of the QVAST tool, using the volcano-structural in- formation available at that time. More recently, Galindo et al. (2016) published a spatial probability map of Lanzarote and Chinijo islands and their submarine flanks. Their analyses were based on kernel density estimation via a linear diffusion process, using chronostratigraphic, volcano-structural and geomorphological data. However, none of these previous studies tackle a thorough volcanic hazard assessment for Lanzarote, although the information they provide should contribute to accomplishing such a task.

In this study, we applied a systematic methodology to conduct long-term volcanic hazard assessment at Lanzarote, based on a review of these previous studies, new generate information and the application of the methodology and e-tools described by Martí et al. (2016a) (see also www.vetools.eu). It includes the sequential application of spatial analysis, temporal analysis, simulation of most probable scenarios and vulnerability analysis. In the case of Lanzarote and due to the scarce available information (e.g. lack of geochronological data), we only conducted the spatial analysis and the simulation of eruptive scenarios. The latter included the main volcanic hazards (fallout, lava flows and pyroclastic density currents, PDCs) documented in the Holocene volcanism in Lanzarote. Results obtained are volcanic hazard scenario maps, which should be considered for land-use planning, elaboration of emergency plans and managing a volcanic crisis in order to protect people, their properties and the geological heritage of the island.

\section{Geographical and geological setting}

The island of Lanzarote (Canary Archipelago, Spain) is the north-easternmost island of the Canaries, located $125 \mathrm{~km}$ far from the western African coast and just $7 \mathrm{~km}$ north of Fuerteventura (Fig. 1). It has an irregular morphology elongated NE-SW, with a maximum altitude of $671 \mathrm{~m}$ (Macizo de Famara), and covers an area of $846 \mathrm{~km}^{2}$, which includes some islets located to the north. It rises approximately $2500 \mathrm{~m}$ from the sea bottom, and most of the volcanic edifice is submerged. Its submerged part is connected to the island of Fuerteventura, both constituting of the same volcanic edifice (Banda et al., 1981).

The basement of the island was constructed during the Oligocene above oceanic sediments of $65-55 \mathrm{Myr}$ old, formed by submarine volcanic materials, plutonic rocks and sediments. It is located on an atypical oceanic crust, at least $11 \mathrm{~km}$ thick (Banda et al., 1981), up to $15 \mathrm{~km}$ (Ortiz et al., 1986; Camacho et al., 2001). The subaerial volcanic history of Lanzarote started about 15.5 Myr ago (Coello et al., 1992) (Fig. 1). In addition to the volcanic materials, there are sedimentary formations, represented by aeolian sands, alluvial and colluvial deposits, mainly Pliocene and Quaternary (Fig. 1) (IGME, 2005).

Two major volcanic cycles have been established during its growth. The first cycle corresponds to the old buildings 
construction (between 11 and 3 Mya) and was characterised by the emission of important volumes of basaltic materials that formed a complex tabular sequence of lavas and pyroclasts gently dipping to the SE and ESE, with isolated outcrops of differentiated trachybasalts and trachytes (Fig. 1) (IGME, 2005). This first stage represents the maximum subaerial growing period (Ancochea et al., 2004), characterised by a high eruptive rate, approximately $0.01-0.02 \mathrm{~km}^{3} \mathrm{ka}^{-1}$ (Coello et al., 1992). Los Ajaches, Famara and Tías Massifs are part of this cycle (Fig. 1) (Carracedo and Rodríguez Badiola, 1993). The second stage (3 Ma - present) was characterised by a period of Pleistocene-Holocene eruptions and historical eruptions (last 600 years) (IGME, 2005). This second subaerial cycle includes the recent activity of Lanzarote and the growth of the small islands located to the north, the Chinijo Archipelago (Fig. 1) (Ancochea et al., 2004). It was characterised by the formation of widespread lava fields covering the materials of the first stage and by the alignment of most vents trending NE-SW. The Chinijo Archipelago was also constructed by hydromagmatic eruptions (De la Nuez et al., 1997). It is marked by the emission of alkaline rocks that evolved to basaltic magmas, with a decrease of the alkalinity, and finally the emission of tholeiitic olivine basalts (Armienti et al., 1991; Carracedo and Rodríguez Badiola, 1993). This second cycle of growth is characterised by continuous volcanic activity with eruptive rates of $0.013-0.027 \mathrm{~km}^{3} \mathrm{ka}^{-1}$ (Coello et al., 1992).

Two historical eruptions took place on the island: the Timanfaya (1730-1736) and the Tao, Nuevo Fuego and Tinguatón (1824) eruptions. Both were multiple-fissure-type eruptions but quite different in size and duration. The Timanfaya eruption lasted 6 years and formed hundreds of vents aligned along a $13-15 \mathrm{~km}$ long fissure, from where lava flows covered almost one-third of the island, erupting a total of $>1.5 \mathrm{~km}^{3}$ of magma (Romero, 1991; Carracedo et al., 1992) (Fig. 2). During the 1824 eruption, three eruptive fissures were formed emitting few pyroclasts and some lava flows, with lengths on the order of hundred metres (Romero, 1991; Carracedo et al., 1992) (Fig. 2).

\section{Methodology}

The first step in any long-term volcanic hazard assessment is the reconstruction of the past eruptive history of the volcano or volcanic area. In this sense, we based our analysis on the Holocene period, from which we identified the different eruptive episodes and their products, since they are better preserved, and established a relative volcano-stratigraphy for all of them. To accomplish this task, previous geological and volcanological studies of Lanzarote were taken into account (Romero, 1991; Carracedo et al., 1992; Ancochea et al., 2004; IGME maps, 2004, and references therein) and completing them with new field work when necessary. We also conducted a structural analysis of the island based on previ- ous geological maps at $1: 25000$ scale (MAGNA, GEODE) and structural studies (Marinoni and Pasquarè, 1994; Galindo et al., 2016) and on remote sensing and morphotectonic analysis of orthophotos (GRAFCAN (http://www.grafcan.es/), topography (lidar digital elevation model (1: 5000), GRAFCAN() and bathymetry (1:100000, IEO). In addition to these volcano-structural features, we also took into account in the computation of volcanic susceptibility the recently modelled regional stress field for the Canary Islands (Geyer et al., 2016).

All abovementioned information was used to define the input parameters necessary to run the different tools we applied to conduct the systematic hazard assessment. These form part of the methodology described by Martí et al. (2016a) (http://www.vetools.eu/), i.e. QVAST (Bartolini et al., 2013) for the spatial analysis (volcanic susceptibility) and VORIS (Felpeto et al., 2007), a GIS-based tool that allows users to simulate fallout, lava flows and PDC scenarios. For ash fall simulations, wind data were compiled from the University of Wyoming Department of Atmospheric Science sounding database (http://weather.uwyo.edu/upperair/sounding.html).

\section{Holocene volcanism}

Holocene eruptions in Lanzarote are restricted to a few subhistorical events (before the last 600 years) at the northeast (Guatiza area) and the historical eruptions located towards the western-central part of the island (Timanfaya area) (Fig. 2d).

Most sub-historical eruptions are fissure type, basic in composition (olivine basalts), with clear Strombolian character (IGME, 2004; Guatiza map). Their main products are proximal fallout pyroclastic deposits and lava flows, mainly of "aa" type, which reached the sea and generated a platform of at least $5 \mathrm{~km}$ length. Lava flows from Mt. de Guenia, Las Calderas de Guatiza, Las Calderas and Las Calderetas (Fig. 2d) come from fissures with trending N30 $\mathrm{E}-\mathrm{N} 37^{\circ} \mathrm{E}$, from $1-1.5 \mathrm{~m}$ to several metres wide. They have associated scoria cones showing a great range of particle sizes (IGME, 2004, Guatiza map).

Hydrovolcanic events also occurred on Lanzarote during the Holocene and previous times. They include both Surtseyan eruptions, caused by the interaction of magma with water in coastal or shallow offshore settings, and inland phreatomagmatic eruptions generated by interaction of erupting magmas with groundwater (Pedrazzi et al., 2013). Several well-preserved hydrovolcanic edifices are identified on the island and islets (Fig. 2b). El Golfo (Martí and Colombo, 1990; Pedrazzi et al. 2013), La Caldera del Cuchillo, Mt. Cavera and Mt. Chica are some examples of hydromagmatic coastal edifices (Fig. 2b, Table 1) (Aparicio et al., 1994). The main characteristics of these eruptions and their subsequent deposits have been gathered from geological maps (IGME, 2004) and some previous studies (Martí and 


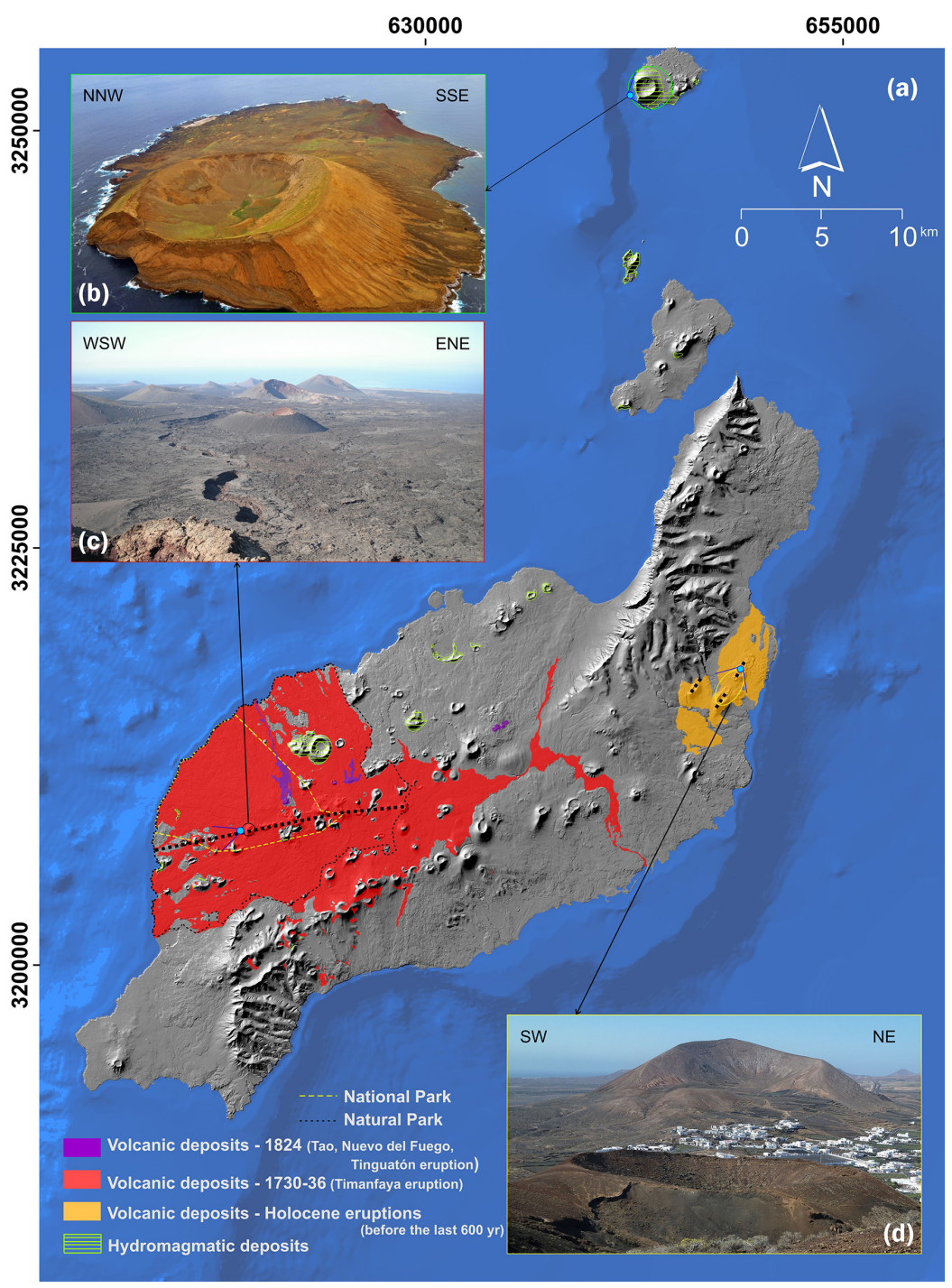

Figure 2. (a) Historical eruptions (red, pink and yellow) and hydromagmatic edifices (green) on Lanzarote; (b) Alegranza hydromagmatic cone with a diameter of $1.2 \mathrm{~km}$; (c) Timanfaya cones; (d) Mt. Guenia and La Caldereta cones. Yellow and black dashed lines define the limits of the Timanfaya National Park and a natural park, respectively.

Colombo, 1990; Carracedo and Rodríguez Badiola, 1991; Aparicio et al., 1994; Pedrazzi et al., 2013; IGME, 2004, Geological Maps). They are summarised in Table 1.

Historical eruptions (both 1730-1736 and 1824) were also of basaltic character. Timanfaya eruption differs from the rest of the Canary Islands' historical eruptions, mainly because of its long duration, magnitude, type and evolution of magmas (Carracedo et al., 1992). It is the second-largest historical effusive eruption in Europe (last 600 years) after Laki (17831785) in Iceland (Thordarson and Self, 1993). A complex fissural volcanic system of approximately $13-15 \mathrm{~km}$ length, with more than 30 cones, was formed during this eruption (Fig. 2c), which produced lava flows and pyroclastic fallouts that covered approximately $226 \mathrm{~km}^{2}$ of Lanzarote's surface (Hernández Pacheco, 1960; Carracedo et al., 1992). The total volume expelled was between 3 and $5 \mathrm{~km}^{3}$ (>1.5 $\left.\mathrm{km}^{3} \mathrm{DRE}\right)$. Lava flows reached the coast, and maximum onshore paths reached up to $21 \mathrm{~km}$ (Fig. 1). This eruption has been studied in detail by Romero (1991), Carracedo et al. (1992) and Solana et al. (2004).

The consequences of 6 years of activity were that more than one-third of farmland and numerous villages of the island were buried by ash and the accompanying degassing resulted in acidic rain fall, which triggered the evacuation and economic collapse of the island (Carracedo et al., 2012; Solana et al., 2004).

The 1824 eruption was characterized by basanitic products. Three cinder cones were formed during 3 months of activity (Tinguatón, Tao and Nuevo del Fuego; Fig. 2), generating an intermittent fissure almost $14 \mathrm{~km}$ in length (Fig. 1). 


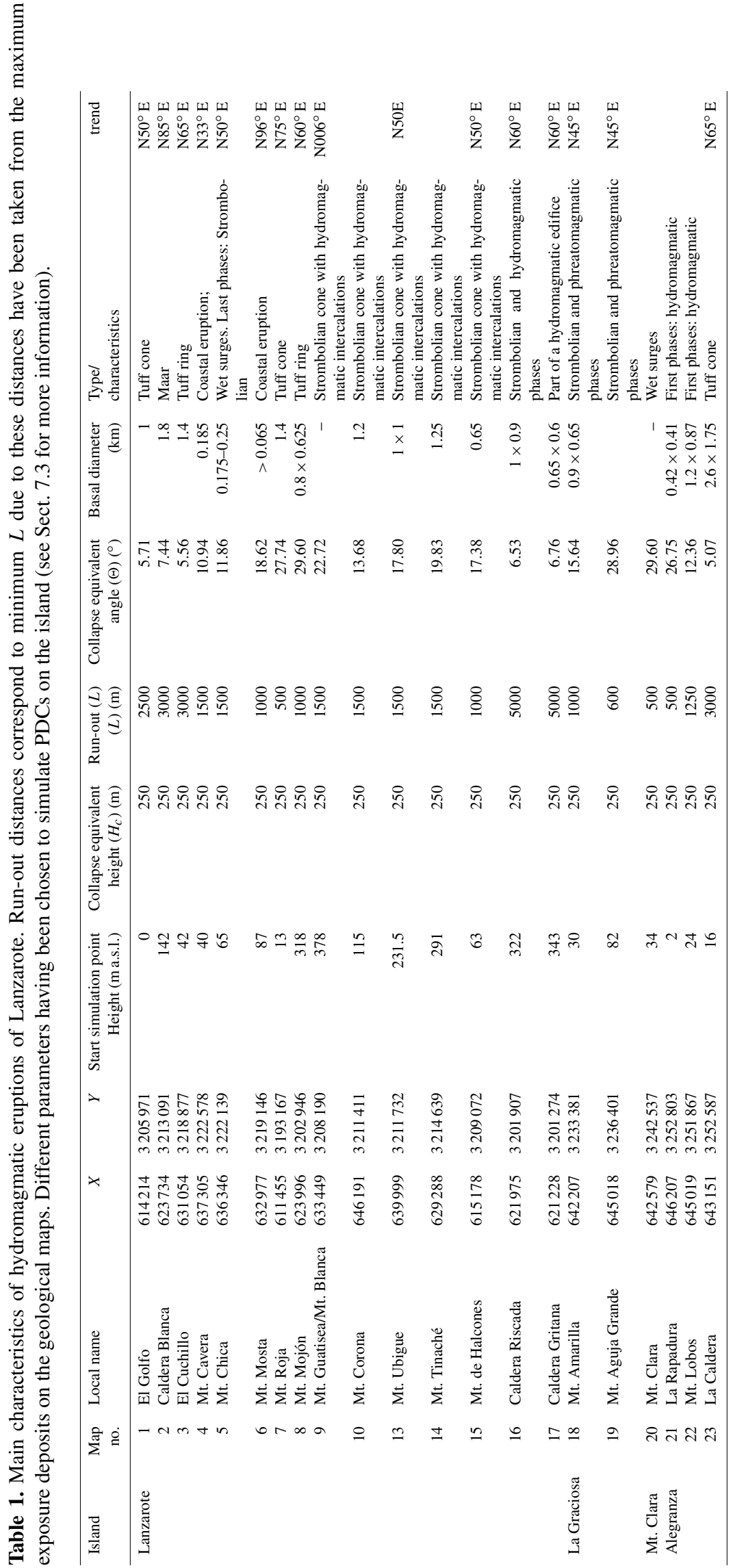


They produced a small lava flow, with a total on land length of $7-8 \mathrm{~km}$, that reached the SW coast of the island.

\section{Volcano-tectonics}

To identify the different structural elements that we considered in the susceptibility analysis, we defined vents and eruptive fissures following the same criteria established by $\mathrm{Be}$ cerril et al. $(2013,2014,2015)$ on El Hierro. Thus, we recognised (i) craters of isolated cinder cones, (ii) craters of coalescent cinder cones belonging to the same eruptive fissure and (iii) craters without an associated cinder cone, both submarine and subaerial. We discarded hornitos and rootless vents as volcanic vents to avoid overvaluing susceptibility analysis, since they are not lava emission centres. Morphologically recognisable submarine eruptive vents were considered as volcanic cinder cones, including those located at the north of Fuerteventura, due to the proximity to Lanzarote and also because they belonged to the same volcanic edifice.

From the volcano-structural study, we obtained different datasets that correspond to vents and eruptive fissures, both onshore and offshore of the island, and onshore faults (Table 2). To identify onshore structures we considered the complete emerged history of the island (from Miocene to Holocene). Volcano-structural datasets were divided according to the age of the structures and their location (onshore or offshore) (Table 2). Thus, we obtained Miocene-Pliocene, Pleistocene and Holocene onshore vents, as well as eruptive fissures, offshore vents and eruptive fissures (Fig. 3, Table 2). Only six faults were identified on the island. The majority of the linear structures (eruptive fissures and faults) follow the NE-SW direction and they are from less than 1 to $15 \mathrm{~km}$ length (Table 2).

\section{Susceptibility analyses}

The spatial probability of a future vent opening, given the past eruptive activity of a volcanic system, is a crucial step for simulating possible future eruptive scenarios, as it will provide indication of where the eruption may start and how the corresponding hazards will distribute (Martí and Felpeto, 2010). The information required to perform this susceptibility analysis is the distribution of the past volcano-structural elements, their age and the regional stress field. The first assumption is that the regional stress field has not changed since the last eruption. Based on this premise, new vents will not form far from the previous ones and, consequently, this volcano-structural information can be used to pinpoint areas where the next eruptions may most likely occur since they represent the sites where previous eruptions have taken place (Connor, 1990; Connor et al., 1992, 2000; Ho, 1992, 1995; Martin et al., 2004; Ho and Smith, 1998; Connor and Conway, 2000; Gaffney et al., 2007; Martí and Felpeto, 2010; Bebbington and Cronin, 2011, Capello et al., 2012; Selva

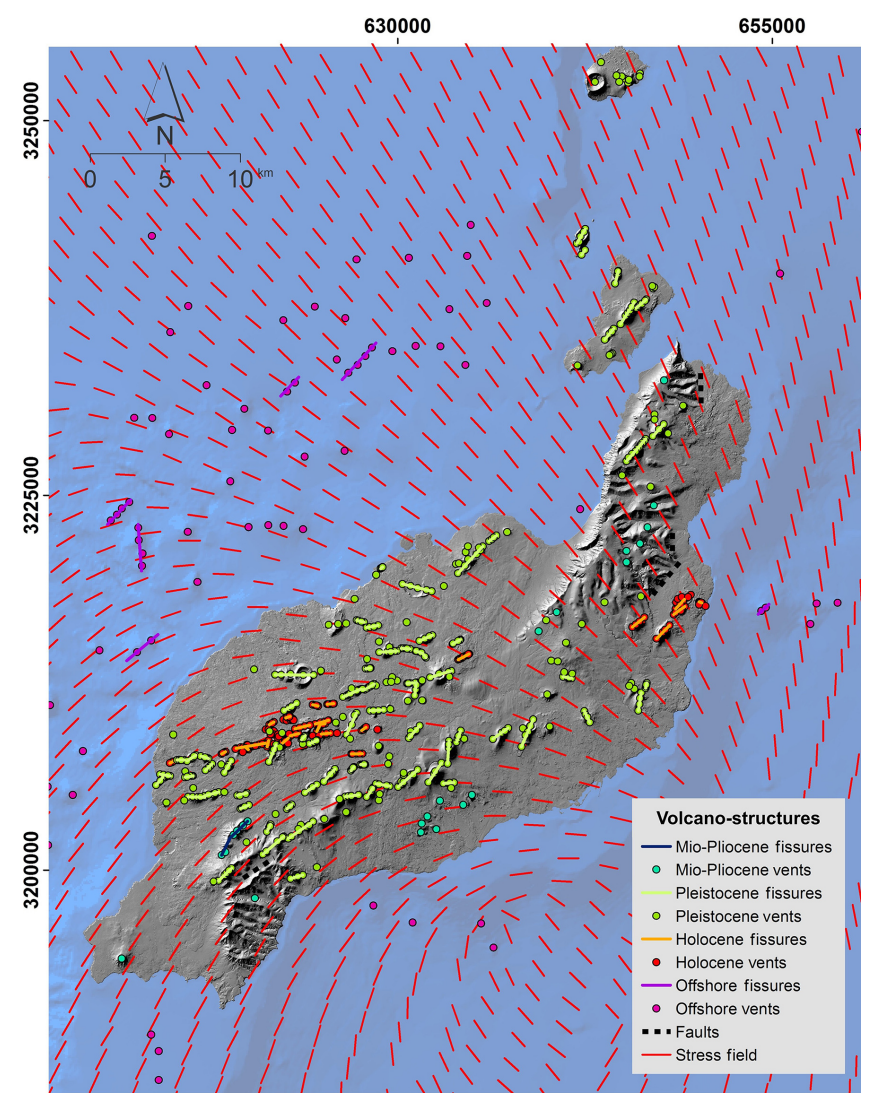

Figure 3. Volcano-structural datasets defined for Lanzarote and used for evaluating spatial probability. Maximum compressive horizontal stress trajectories are also indicated (red lines).

et al., 2012; Le Corvec et al., 2013; Bartolini et al., 2013; Bevilacqua et al., 2015; Martí et al., 2016b). Other kinds of data such as geophysical information or the stress field configuration of a volcanic area, if available, should also be used to forecast more precisely the most probable areas to host future vents (Martí and Felpeto, 2010; Martí et al., 2016b). In particular, the stress field is a key parameter controlling magma generation, magma migration and magma accumulation inside the volcanic system, as well as the location, geometry and the distribution of the resulting volcanism at surface (Martí et al., 2016b). Therefore, knowing the stress configuration in the lithosphere at any scale (i.e. local, regional and plate scale) is important to understand volcanism distribution and, subsequently, to predict the location of future eruptions (Martí et al., 2016b). For that reason, in this work we also considered the regional stress field configuration in Lanzarote (Geyer et al., 2016), which updates the previous susceptibility maps developed by Bartolini et al. (2013) and Galindo et al. (2016).

We used the QVAST tool (QGIS for volcanic susceptibility; Bartolini et al., 2013) to generate a quantitative assessment of volcanic susceptibility in the island. This tool is backed on a probabilistic method that calculates a kernel 
Table 2. Number of identified volcanic structures on Lanzarote Island, according to their ages and location.

\begin{tabular}{lrrrr}
\hline Volcano structures & \multicolumn{2}{c}{ Onshore } & Offshore \\
\cline { 2 - 4 } & Miocene-Pliocene & Pleistocene & Holocene & \\
\hline Vents & 23 & 419 & 171 & 102 \\
Eruptive fissures & 1 & 69 & 25 & 9 \\
Faults & 6 (no associated age) & & - \\
\hline
\end{tabular}

function at each data location, based on the distance from nearby volcanic structures, to estimate probability density functions). One of the most important factors to determine this density distribution is the smoothing parameter, also known as smoothing factor or bandwidth, which represents the degree of randomness in the distribution of past events.

In this study, we applied the least-square cross validation (LSCV) method to evaluate the bandwidth of each dataset (Cappello et al., 2012, 2013; Del Negro et al., 2013), as it better represents the geometry of the vents distribution, NESW elongated. The dataset used is our volcano-structural information: vents, onshore and offshore eruptive fissures and faults (Fig. 3). The bandwidth parameter $(h)$ obtained for each of the defined datasets was (Table 3) (i) $2527 \mathrm{~m}$ for vents and fissures of the Miocene-Pliocene, (ii) $2808 \mathrm{~m}$ for vents and fissures of the Pleistocene, (iii) $560 \mathrm{~m}$ for the vents and fissures of the Holocene, (iv) $6508 \mathrm{~m}$ for vents and fissures offshore and (v) $20808 \mathrm{~m}$ for faults (Table 3).

Considering the regional stress field model by Geyer et al. (2016) and the different ages of the volcano-structural elements, the expert judgement elicitation assigned the following weights to each dataset: (i) 0.107 for vents and fissures of the Miocene-Pliocene, (ii) 0.207 for vents and fissures of the Pleistocene, (iii) 0.357 for vents and fissures of the Holocene, (iv) 0.193 for offshore vents and fissures and (v) 0.136 for faults (Table 3 ). In detail, the relevance and reliability values (Table 3) (Martí and Felpeto, 2010) have been assigned as follows: relevance was given through an elicitation of expert judgment procedure (Aspinall, 2006) among the members of the Group of Volcanology of Barcelona (GVB-CSIC) and external collaborators (14 experts in total); reliability was considered as maximum in all the datasets (value of 1), since all of them come from previously published volcano-structural studies and direct field observations.

The total susceptibility map was thus obtained via a weighted sum and modelled in a non-homogeneous Poisson process (Fig. 4).

\section{Eruptive scenarios}

\subsection{Fallout scenarios}

Fallout scenarios were obtained using VORIS 2.0.1 tool (Felpeto et al., 2007). The input data regarding the eruptive

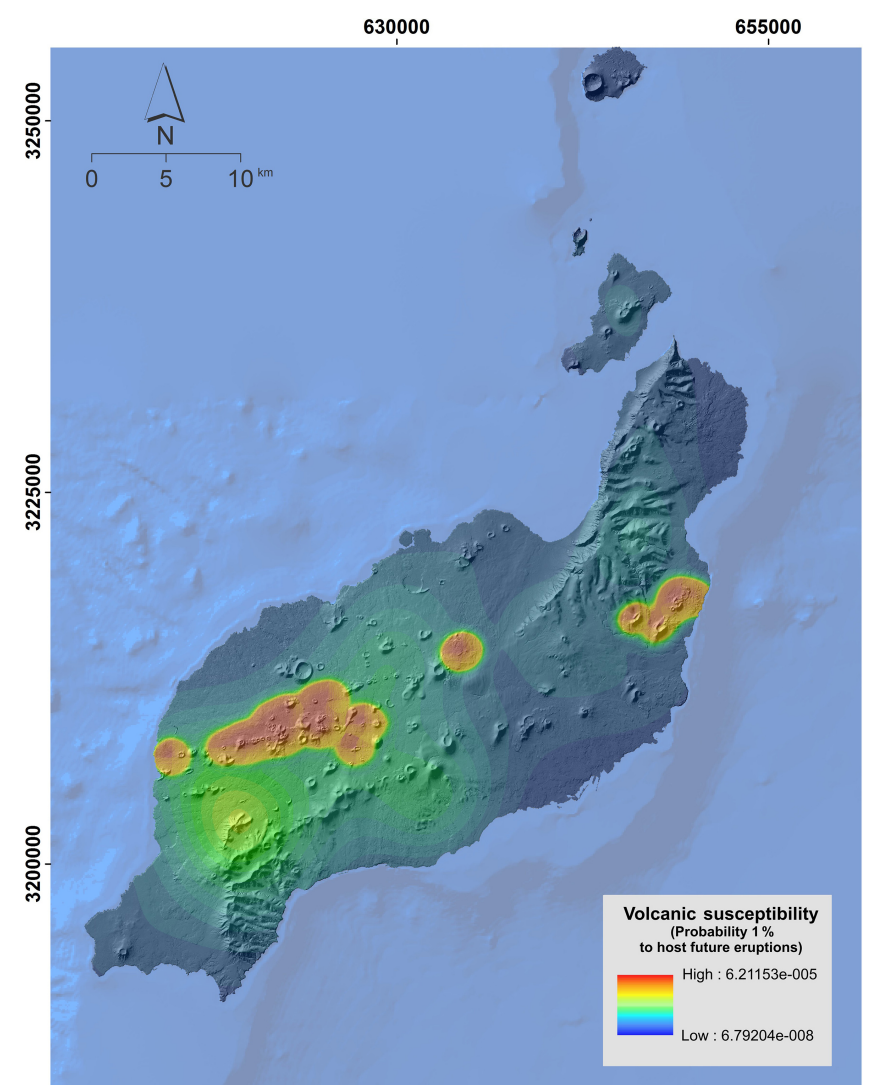

Figure 4. Volcanic susceptibility map of Lanzarote Island. The highest probability (0.00006) of new vent opening is obtained along a NE-SW area. High probabilities are also observed in the south of the island.

column and ash particle size were inferred from historical eruptions published data (Romero, 1991; Carracedo et al., 1992; Ancochea et al., 2004; IGME maps, 2004, and references therein). We simulated one scenario with the same eruptive parameters as the 1824 eruption considering a maximum column height of $3 \mathrm{~km}$ and a total emitted volume of $0.02 \mathrm{~km}^{3}$ (Table 4), assuming this scenario is the most probable in the near future in the island.

All simulations were conducted from one of the pixels located in the highest spatial probability area, and data inputs of wind velocities were compiled from the University of Wyoming Department of Atmospheric Science sounding database (http://weather.uwyo.edu/upperair/ 
Table 3. Parameters used for performing susceptibility analysis.

\begin{tabular}{lllrr}
\hline No. & Structural datasets & Age & Bandwidth & Weight \\
\hline 1 & Miocene-Pliocene vents and eruptive fissures & $15-2.5 \mathrm{Ma}$ & 2527 & 0.107 \\
2 & Pleistocene vents and eruptive fissures & $2.5-11.7 \mathrm{ka}$ & 2808 & 0.207 \\
3 & Holocene vents and eruptive fissures & last $11.7 \mathrm{ka}$ & 560 & 0.357 \\
4 & Offshore vents and eruptive fissures & unknown ages & 6508 & 0.193 \\
5 & Faults & unknown ages & 20808 & 0.136 \\
\hline
\end{tabular}

Table 4. Main characteristics of the historical and Holocene eruptions and parameters used for scenario simulations.

\begin{tabular}{|c|c|c|c|c|c|}
\hline \multirow[t]{2}{*}{$\begin{array}{l}\text { Geological } \\
\text { process hazard }\end{array}$} & \multicolumn{5}{|c|}{$\begin{array}{l}\text { These parameters are mainly derived } \\
\text { from } 1730-1736 \text { and } 1824 \text { eruptions }\end{array}$} \\
\hline & $\begin{array}{l}\text { Max. } \\
\text { length }(\mathrm{km})\end{array}$ & $\begin{array}{l}\text { Mean } \\
\text { length }(\mathrm{km})\end{array}$ & $\begin{array}{l}\text { Min. } \\
\text { length }(\mathrm{km})\end{array}$ & $\begin{array}{l}\text { Mean } \\
\text { thickness (m) }\end{array}$ & $\begin{array}{l}\text { Total emitted } \\
\text { volume }\left(\mathrm{km}^{3}\right)\end{array}$ \\
\hline \multirow[t]{2}{*}{ Lava flow } & $35 / 25$ & $5-7$ & 1.5 & 10 & $0.02-4$ \\
\hline & \multicolumn{4}{|c|}{$\begin{array}{l}\text { Run-out }(\mathrm{km}) \text {; from hydromagmatic } \\
\text { eruptions or phreatic phases }\end{array}$} & \\
\hline Pyroclastic density current & \multicolumn{2}{|r|}{$0.5-3$} & \multicolumn{2}{|c|}{$\begin{array}{c}5-29 \\
\text { Size particles }(\Phi)\end{array}$} & \\
\hline Fallout & \multicolumn{2}{|r|}{$3-5$} & \multicolumn{2}{|c|}{ From -6 to 2} & \\
\hline
\end{tabular}

sounding.html) at different vertical heights (500, 1500, 2500 and $3500 \mathrm{~m})$. We focused the attention of our study on the fallout scenarios for the NE direction (Fig. 5a), which represents the typical north-east trade wind that characterises the Canary Islands latitude, and for all wind rose directions (Fig. 5b). Results are shown in Fig. 5. Particle sizes ( -6 to $2 \phi)$ were considered in all simulations, thereby covering the entire range of particle sizes observed in the field.

In the case of fallout scenarios we have only reproduced two scenarios (NE wind direction and entire wind rose directions) from a single vent located in the area with highest susceptibility value instead of making the calculation from all pixels of the map. The reason is that the ash fall process does not depend on the topography but only on the position of the vent and wind direction, in addition to all eruptive parameters. Therefore, the use of the volcanic susceptibility map as base map for simulating ash fall would have required almost 150000 simulations, corresponding to the number of pixels of the susceptibility model. All these simulations together would have given a superposition of many plumes that would cover the entire island, not particularly useful for the purposes of this study.

\subsection{Lava flow scenarios}

The most expected processes associated with an effusive eruption in Lanzarote are lava flows. Lava flow scenarios were performed for the whole island using VORIS 2.0.1 tool (Felpeto et al., 2007) and as single vent scenarios reproducing the lava flows of the 1730-1736 and 1824 eruptions
(Fig. 4a, b). For the first case, we used the whole susceptibility map (Fig. 4), only taking into account the on-land pixels. For single vent scenarios, we used only those pixels with the highest spatial probability values. Lava flow input parameters were constrained by maximum flow lengths and thicknesses taken from historical eruptions and field measurements. We assumed flow lengths up to $35 \mathrm{~km}$ because the 1730-1736 eruption poured out lavas that reached the sea after paths of $21 \mathrm{~km}$ onshore. Maximum lava flow length considered for the 1824 eruption was $7 \mathrm{~km}$, while for the whole lava flow map a maximum length was $25 \mathrm{~km}$, taking into account lava lengths from the 1730-1736 eruption. The thickness used as input for all the models was $10 \mathrm{~m}$. The results provide two single vent scenario maps and a total map that gives the probability that any particular cell is invaded by a lava flow (Fig. 6). The total lava flow map was performed with a cell size of $75 \mathrm{~m}$, thus optimising the result and computed time.

\subsection{Pyroclastic density current scenarios}

Hydromagmatic eruptions have also occurred on Lanzarote in recent times and have generated a wide variety of PDCs deposits. It is possible to recognise pure hydromagmatic edifices and also Strombolian edifices with phreatomagmatic phases (García-Cacho and Romero, 2000). For that, we have mainly simulated hydromagmatic eruptions in areas close to the previous vents but also some phreatomagmatic phases that could occur together with Strombolian activity. PDCs were simulated with an energy cone model (Sheridan and Malin, 1983) using as input parameters topography, the col- 


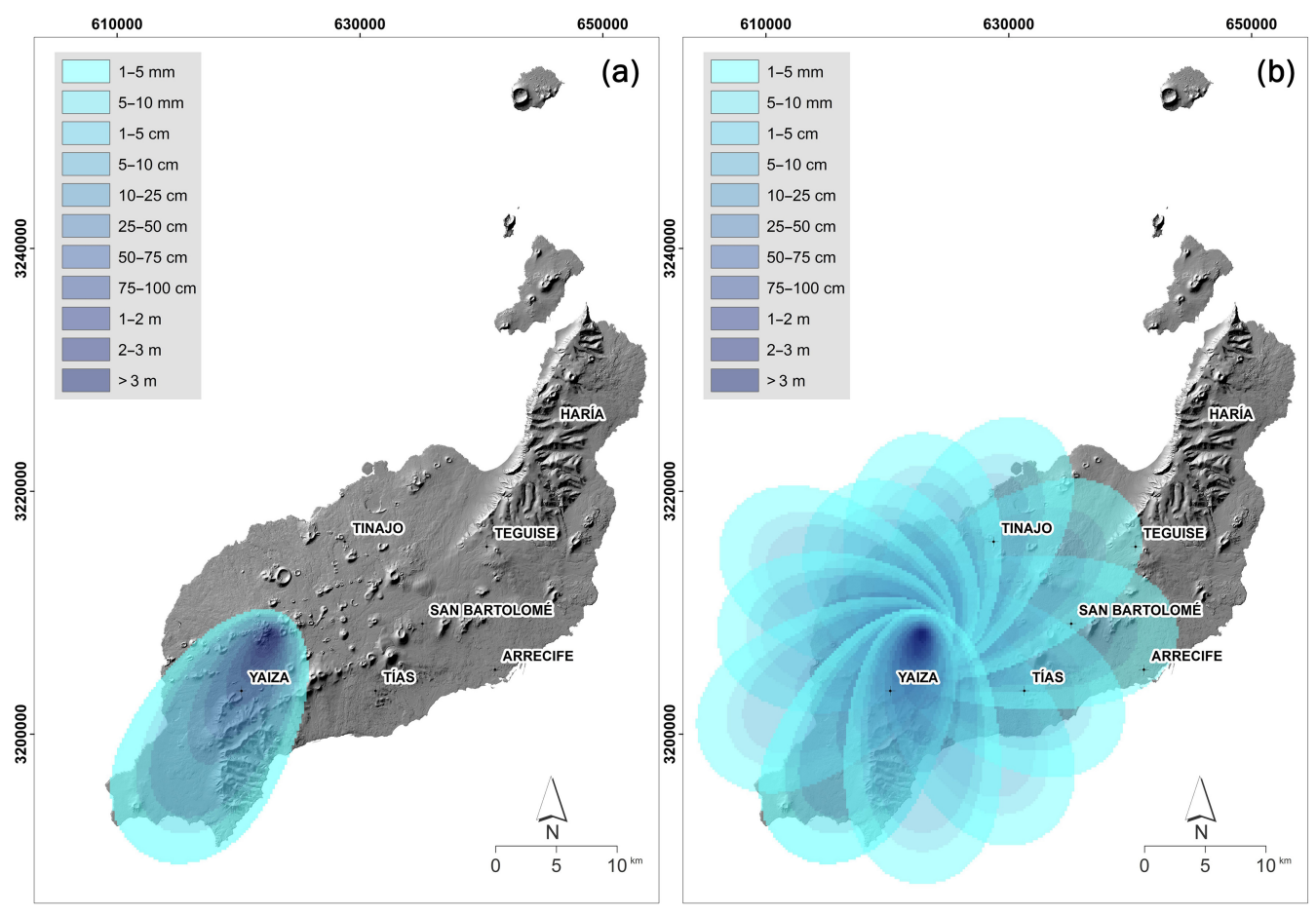

Figure 5. Fallout scenarios at the highest probability vent for the NE wind direction and for all wind rose directions performed with VORIS 2.0.1. (a) NE wind simulation assuming a Strombolian eruption; (b) 1824 eruption. Main localities have been placed in order to show which ones would be affected by the ash fall dispersion.

lapse equivalent height $(H)$ and the collapse equivalent angle $(\theta)$, which is obtained through the arctangent of the ratio between $H_{c}$ and $L$, where $L$ represents the run-out length (Felpeto et al., 2007; Toyos et al., 2007).

$L$ values were considered to be equivalent to the most distal exposure of PDC deposits found on the island (Tables 1 and 4), which correspond to lengths from 0.5 to $3 \mathrm{~km}$. $H$ was assumed to be $250 \mathrm{~m}$ for all simulations, considering similar kinds of eruptive styles for these hydromagmatic eruptions (Toyos et al., 2007). We simulated PDCs with $\theta$ in the range of around $5-29^{\circ}$ (low values for base-surge-type explosions and high values for PDCs derived from column collapse) (Sheridan and Malin, 1983) (Tables 1 and 4). Figure 7 shows coverage areas with different column collapse equivalent angles, reaching the deposits up to almost $15 \mathrm{~km}$. Each simulation is associated with previous PDCs occurred on the island; that is, similar parameters and close areas of previous PDCs deposits have been considered. Numbers in Fig. 7 are related to those in Table 1.

\section{Discussion and conclusions}

Lanzarote is one of the four islands of the Canary Archipelago that had important eruptive activity during the last 600 years (historical period), the Timanfaya eruption in 1730-1736 being the second largest historical eruption occuring on a European territory. This, together with the fact that it is the third preferred tourist destination of the Canary Islands, classifies Lanzarote as an active volcanic island for which a precise hazard assessment is urgently required.

Past on-land volcanism has been mainly characterised by multiple-fissure-type eruptions of basaltic magmas, generating lava flows of variable lengths and small-to-medium-sized cinder cones, so we should expect future eruptions being of the same type. A few hydromagmatic eruptions have also been recognised along the coast line or close to it, which generated Surtseyan activity when eruptive magma interacted directly with sea water (e.g. El Golfo, Pedrazzi et al., 2013) or phreatomagmatic pulses when magma interacted with a saltwater intrusion near the coast (e.g. El Cuchillo, Aparicio et al., 1994). In this case, different types of dilute PDC deposits were produced, together with ballistics and fallout, reaching distances up to $15 \mathrm{~km}$ from the vent. Moreover, the large number of well-preserved cones observed on the submerged slopes of the island suggests that the number of submarine eruptions in recent times may be similar or significantly higher than those from on-land. This suggests that a 

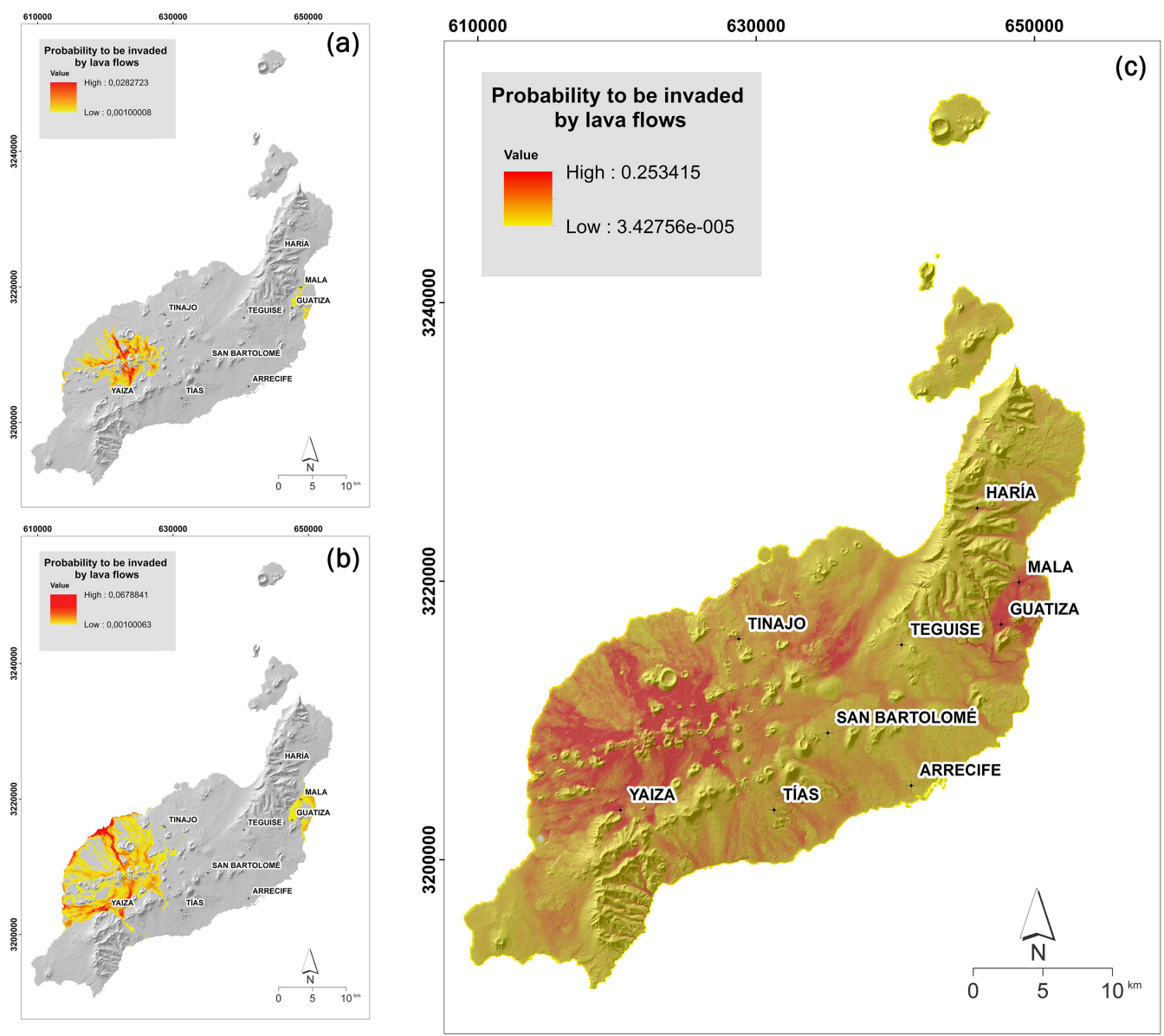

Figure 6. Lava flow scenarios for Lanzarote performed with VORIS 2.0.1. (a) Timanfaya scenario; (b) 1824 eruption scenario; (c) total lava flow map. Red colours are those areas with the highest probability to be invaded by lava flows.

submarine eruption scenario should be considered as highly probable. Unfortunately, the lack of geochronological data precludes establishing the eruption recurrence in Lanzarote, so not allowing to conduct a temporal hazard assessment and to quantitatively identify the most probable eruptive scenarios. Therefore, our hazard assessment is restricted to the onland volcanism, which does not mean that a subaerial eruption is the one with the highest probability of occurrence on Lanzarote in the near future.

The spatial analysis revealed that the area with the highest probability of hosting a new subaerial eruption is mainly located in the same area than the previous 1824 and Timanfaya eruptions (Fig. 4). This is mainly due to the fact that the best-preserved vents are concentrated in this zone (Fig. 3) but also that the current stress field is compatible with orientation of fractures that governed these most recent eruptions (Fig. 3). Our results slightly contrast with those recently presented by Galindo et al. (2016). The differences observed for the on-land areas may be due to the different method used in both studies. Our study follows the method of Cappello et al. (2013) since it is a well-tested method successfully ap- plied to volcanic fields such as Etna, El Hierro, Deception Island or Pico (Cappello et al., 2012, 2015; Becerril et al., 2013; Bartolini et al., 2014), which show similar behaviour to Lanzarote; we also considered it to be more appropriate to model volcanic susceptibility in this particular case rather than to develop a new model as was done by Galindo et al. (2016).

Simulation of the different volcanic hazards that may be produced in subaerial eruptions on Lanzarote revealed the opening of new eruptive fissures in the highest-probability areas. Assuming a new typical Strombolian eruption and the typical winds of the Canary Islands (NE-SE winds) would imply the dispersion of the volcanic ash mainly towards the southern part of the island. As mentioned before, this area hosts a high number of tourist resorts; therefore, in case of an eruption, a large number of people would have to be evacuated (Fig. 5).

Lava flows are mostly constrained to the area around their vents. This implies that, according to the hazard map, if we expect a typical Strombolian eruption with lava flow emission, those areas that could be affected by this process are 


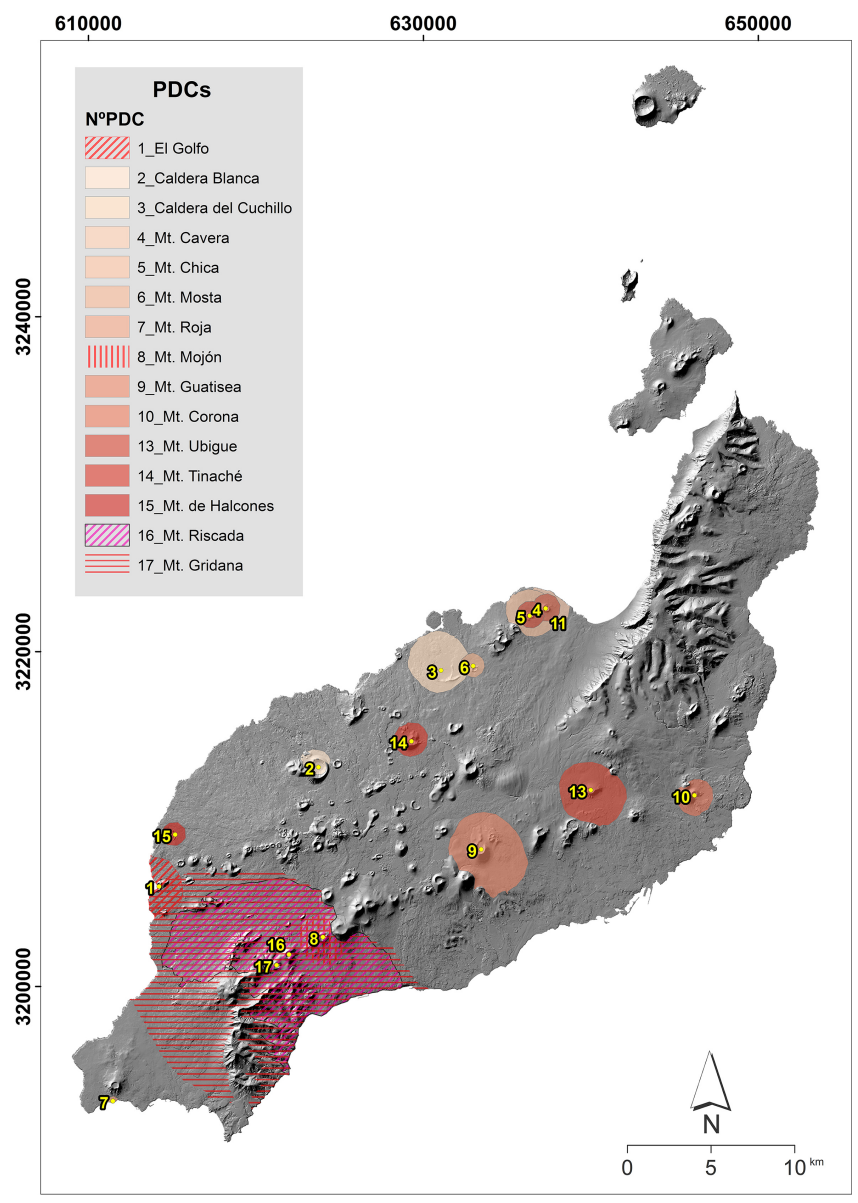

Figure 7. PDC scenarios performed with VORIS 2.0.1. Shaded areas with different collapse equivalent heights $\left(H_{C}\right)$ and collapse equivalent angles $(\theta)$ (see the text for more detail). Different symbols (dashed, filled and coloured) have been used to show the limits of each PDC. Yellow dots indicate the simulation starting point.

mainly located around the Timanfaya National Park. This includes two protected areas (a national park and a natural park), but it does not host too many towns or much infrastructure. If, however, we expect larger eruptions in terms of emitted volume, the run-out distances of the lava flows would be longer, affecting numerous towns and villages around the Timanfaya area and others located to the north (Guatiza, Mala in Fig. 6). The rest of the island would have a lower chance of being inundated by lava flows.

Finally, the occurrence of PDC is more restricted to areas close to the coast, where the majority of the identified past hydromagmatic events are concentrated, being in age older than the most recent eruptions. However, such scenarios must also be considered as they may have larger impacts than normal Strombolian eruptions.
Data availability. Wind data series were used from the University of Wyoming Department of Atmospheric Science sounding database. Average of wind height, direction and instensity were used to perform ashfall simulations.

Competing interests. The authors declare that they have no conflict of interest.

Acknowledgements. This research has been financially supported by the European Commission's Humanitarian Aid and Civil Protection department (EC ECHO project SI.2.695524 (VeTOOLS) 2015-2016). Joan Martí is grateful for the MECD (PRX16/00056) grant. We would like to thank the two reviewers of our paper: José Luis Macias and Sophie Mossoux. Their comments and corrections have substantially improved the paper.

Edited by: Giovanni Macedonio

Reviewed by: José Luis Macías and Sophie Mossoux

\section{References}

Ancochea, E., Barrera, J. L., Bellido, F., Benito, R., Brändle, J. L., Cebriá, J. M., Coello, J., Cubas, C. R., De La Nuez, J., Doblas, M., Gómez, J. A., Gómez, J. A., Hernán, F., Herrera, R., Huertas, M.J., López-Ruiz, J., Martí, J., Muñoz, M., and Sagrado, J.: Canarias y el vulcanismo neógeno peninsular. En: Geología de España, edited by: Vera, J. A., SGE-IGME, Madrid, 635-682, 2004.

Aparicio, A., Araña, V., and Díez-Gil, J. L.: Una erupción hidromágmática en la isla de Lanzarote: La Caldera de El Cuchillo. Elementos de Volcanología no. 3. Serie Casa de Los Volcanes, Excmo. Cabildo Insular de Lanzarote, 109-120, 1994.

Armienti, P., Innocenti, F., Pareschi, M. T., Pompilio, M., and Rocchi, S.: Crystal Population Density in not Stationary Volcanic Systems: Estimate of Olivine Growth Rate in Basalts of Lanzarote (Canary Islands), Mineral. Petrol., 44, 181-196, 1991.

Aspinall, W. P.: Structured elicitation of expert judgment for probabilistic hazard and risk assessment in volcanic eruptions, in: Statistics in Volcanology: Special Publication of IAVCEI, edited by: Mader, H. M., Coles, S. G., Connor, C. B., and Connor, L. J., 1. Geol. Soc. London, 15-30, 2006.

Banda, E., Dañobeitia, J. J., Suriñach, E., and Ansorge, J.: Features of crustal structure under the Canary Islands, Earth Planet. Sc. Lett., 55, 11-24, 1981.

Bartolini, S., Cappello, A., Martí, J., and Del Negro, C.: QVAST: a new Quantum GIS plugin for estimating volcanic susceptibility, Nat. Hazards Earth Syst. Sci., 13, 3031-3042, https://doi.org/10.5194/nhess-13-3031-2013, 2013.

Bartolini, S., Geyer, A., Martí, J., Pedrazzi, D., and Aguirre-Díaz, G.: Volcanic hazard on deception Island (South Shetland Islands, Antarctica), J. Volcanol. Geotherm. Res., 285, 150-168, https://doi.org/10.1016/j.jvolgeores.2014.08.009, 2014.

Bebbington, M. S. and Cronin, S.: Spatio-temporal hazard estimation in the Auckland Volcanic Field, New Zealand, with a new event-order model, B. Volcanol., 73, 55-72, https://doi.org/10.1007/s00445-010-0403-6, 2011. 
Becerril, L., Cappello, A., Galindo, I., Neri, M., and Del Negro, C.: Spatial probability distribution of future volcanic eruptions at El Hierro Island (Canary Islands, Spain), J. Volcanol. Geoth. Res., 257, 21-30, 2013.

Becerril, L., Bartolini, S., Sobradelo, R., Martí, J., Morales, J. M., and Galindo, I.: Long-term volcanic hazard assessment on El Hierro (Canary Islands), Nat. Hazards Earth Syst. Sci., 14, 18531870, https://doi.org/10.5194/nhess-14-1853-2014, 2014.

Becerril, L., Galindo, I., Martí, J., and Gudmundsson, A.: ThreeArmed Rifts or Masked Radial Pattern of Eruptive Fissures? The Intriguing Case of El Hierro Volcano (Canary Islands), Tectonophysics, 33-47, 647-648, 2015.

Bevilacqua, A., Isaia, R., Neri, A., Vitale, S., Aspinall, W. P., Bisson, M., Flandoli, F., Baxter, P. J., Bertagnini, A., Esposti Ongaro, T., Iannuzzi, E., Pistolesi, M., and Rosi, M.: Quantifying volcanic hazard at Campi Flegrei caldera (Italy) with uncertainty assessment: 1. Vent opening maps, J. Geophys. Res.-Sol. Ea., 120, 2309-2329, https://doi.org/10.1002/2014JB011775, 2015.

Camacho, A. G., Montesinos, F. G., Vieira, R., and Arnoso J.: Modelling of crustal anomalies of Lanzarote (Canary Islands) in light of gravity data, Geophys. J. Int., 147, 403-414, 2001.

Cappello, A., Neri, M., Acocella, V., Gallo, G., Vicari, A., and Del Negro, C.: Spatial vent opening probability map of Mt Etna volcano (Sicily, Italy), B. Volcanol., 74, 2083-2094, 2012.

Cappello, A., Bilotta, G., Neri, M., and Del Negro, C.: Probabilistic modeling of future volcanic eruptions at Mount Etna, J. Geophys. Res., 118, 1925-1935, https://doi.org/10.1002/jgrb.50190, 2013.

Cappello, A., Zanon, V., Del Negro, C., Ferreira, T. J. L., and Queiroz, M. G. P. S.: Exploring lava-flow hazards at Pico Island, Azores Archipelago (Portugal), Terra Nova, 27, 156-161, 2015.

Carracedo, J. C. and Rodríguez Badiola, E.: Evolución geológica y magmática de la isla de Lanzarote, Islas Canarias, Rev. Acad. Canaria Ciencias, 4, 25-58, 1993.

Carracedo, J. C., Badiola, E. R., and Soler, V.: The 1730-1736 eruption of Lanzarote, Canary Islands: a long, high-magnitude basaltic fissure eruption, J. Volcanol. Geotherm. Res., 53, 239250, 1992.

Coello, J. Cantagrel, J. M., Hernan, F., Fuster, J. M., Ibarrola E., Ancochea, E., Casquet, C., Jamond, C., Diaz, de Teran, J. R., and Cendrero, A.: Evolution of the eastem volcanic ridge of the Canary Islands based on new K-Ar data, J. Volcanol. Geotherm. Res., 53, 251-274, 1992.

Connor, C., Stamatakos, J. A., Ferrill, D. A., Hill, B. E., Ofoegbu, G. I., Conway, F. M., Sagar, B., and Trapp, J.: Geologic factors controlling patterns of small-volume basaltic volcanism: application to a volcanic hazards assessment at Yucca Mountain, Nevada, J. Geophys Res., 105, 417-432, 2000.

Connor, C. B.: Cinder Cone Clustering in the TransMexican Volcanic Belt: Implications for Structural and Petrologic Models, J. Volcanol. Geotherm. Res., 95, 395-405, 1990.

Connor, C. B. and Conway, F. M.: Basaltic volcanic fields, in: Encyclopedia of Volcanoes, edited by: Sigurdsson, H., Academic Press, New York, 331-343, 2000.

Connor, C. B., Condit, C. D., Crumpler, L. S., and Aubele, J. C.: Evidence of Regional Structural Controls on Vent Distribution: Springerville Volcanic Field, Arizona, J. Geophys. Res., 97, 12349-12359, 1992.
De la Nuez, J., Quesada, M. L., and Alonso, J. J.: Los volcanes de los islotes al norte de Lanzarote, Fundación César Manrique, Teguise, Lanzarote, 233 pp., 1997.

Felpeto, A.: Modelización física y simulación numérica de procesos eruptivos para la generación de mapas de peligrosidad volcánica, PhD thesis, University of Madrid 250 pp., 2002.

Felpeto, A., Araña, V., Ortiz, R., Astiz, M., and García, A.: Assessment and modelling of lava flow hazard on Lanzarote (Canary Islands), Nat. Hazards, 23, 247-257, 2001.

Felpeto, A., Martí, J., and Ortiz, R.: Automatic GIS-based system for volcanic hazard assessment, J. Volcanol. Geoth. Res., 166, 106-116, https://doi.org/10.1016/j.jvolgeores.2007.07.008, 2007.

Gaffney, E. S., Damjanac, B., and Valantine, G. A. Localization of volcanic activity: 2. Effects of pre-existing structure, Earth Planet. Sc. Lett., 263, 323-338, 2007.

Galindo, I., Romero, M. C., Sánchez, N., and Morales, J. M.: Quantitative volcanic susceptibility analysis of Lanzarote and Chinijo Islands based on kernel density estimation via a linear diffusion process, Sci. Rep. 6, 27381, https://doi.org/10.1038/srep27381, 2016.

García-Cacho, L. and Romero, C.: Fenómenos hidromagmáticos en Lanzarote, in: Curso Internacional de Volcanología y Geofísica Volcánica, edietd by: Astiz, M. and García, A., Cabildo Insular de Lanzarote, 153-162, 2000.

Geyer, A., Martí, J., and Vilaseñor, A.: First-order estimate of the Canary Islands plate-scale stress field: Implications for volcanic hazard assessment, Tectonophysics, 679, 125-139, 2016.

Hernández-Pacheco, E.: En relación a las grandes erupciones volcánicas del Siglo XVIII y 1824, en Lanzarote, El Museo Canario, 73, 239-254, 1960.

Ho, C. H.: Risk assessment for the Yucca Mountain high-level nuclear waste repository site: estimation of volcanic disruption, Math. Geol., 24, 347-364, 1992.

Ho, C. H.: Sensitivity in volcanic hazard assessment for the Yucca Mountain high-level nuclear waste repository site: the model and the data, Math. Geol., 27, 239-258, 1995.

Ho, C. H. and Smith, E. I. A spatial-temporal/3-D model for volcanic hazard assessment: application to the Yucca Mountain region, Nevada, Math. Geol., 30, 497-510, 1998.

IGME: Memorias mapas MAGNA Lanzarote 1:25000, Hojas: Guatiza, Arrecife, Yaiza, Haría, Teguise, Soo, Tinajo, Femés, Graciosa, Alegranza, Caleta de Sebo. Instituto Geológico y Minero de España, Madrid, 2004.

IGME: Mapa geológico de España escala 1:100.000, 88, Lanzarote, Instituto Geológico y Minero de España, Madrid, 2005.

Le Corvec, N., Spörli, K. B., Rowland, J., and Lindsay, J.: Spatial distribution and alignments of volcanic centers: Clues to the formation of monogenetic volcanic fields, Earth Sci. Rev., 124, 96-114, 2013.

Marinoni, L. B. and Pasquarè, G.: Tectonic evolution of the emergent part of a volcanic ocean island: Lanzarote, Canary Islands, Tectonophysics, 239, 111-137, 1994.

Martí, J. and Colombo, F.: Estratigrafía, sedimentología y mecanismos eruptivos del edificio hidromagmático de El Golfo (Lanzarote), Bol. Geol. Min., 101, 560-579, 1990.

Martí, J. and Felpeto, A.: Methodology for the computation of volcanic susceptibility. An example for mafic and felsic eruptions on 
Tenerife (Canary Islands), J. Volcanol. Geoth. Res., 195, 69-77, https://doi.org/10.1016/j.jvolgeores.2010.06.008, 2010.

Martí, J., Bartolini, S., and Becerril, L.: The challenge of conducting volcanic hazard assessment and risk management, What the VeTOOLS project can offer us?, EOS, https://doi.org/10.1029/2016EO054161, 2016a.

Martí, J., López, C., Bartolini, S., Becerril, L., and Geyer, A.: Stress controls of monogenetic volcanism: a review, Front. Earth Sci., 4, 106, https://doi.org/10.3389/feart.2016.00106, 2016 b.

Martin, A. J., Umeda, K., Connor, C. B., Weller, J. N., Zhao, D., and Takahashi, M.: Modeling long-term volcanic hazards through Bayesian inference: an example from the Tohuku volcanic arc, Japan, J. Geophys. Res., 109, B10208, https://doi.org/10.1029/2004JB003201, 2004.

Ortiz, R., Araña, V., and Valverde, C.: Aproximación al conocimiento del mecanismo de la erupción de 1730-1736 en Lanzarote: Anales de Física Serie B. 82 Especial Issue, "Física de los Fenómenos Volcánicos”, 127-142 pp., 1986.

Pedrazzi, D., Martí, J., and Geyer, A.: Stratigraphy, sedimentology and eruptive mechanisms in the tuff cone of El Golfo (Lanzarote, Canary Islands), B. Volcanol., 75, 1-6, https://doi.org/10.1007/s00445-013-0740-3, 2013.
Romero, C.: La erupción de Timanfaya (Lanzarote, 1730-1736), Análisis documental y estudio geomorfológico (Universidad de La Laguna, secretariado de publicaciones, La Laguna, 1991.

Selva, J., Orsi, G., Di Vito, M., Marzocchi, W., and Sandri, L.: Probability hazard map for future vent opening at the Campi Flegrei caldera, Italy, B. Volcanol., 74, 497-510, 2012.

Sheridan, M. F. and Malin, M. C.: Application of computer-assisted mapping to volcanic hazard evaluation of surge eruption: Vulcano, Lipari, Vesuvius. Explosive Volcanism, J. Volcanol. Geoth. Res., 17, 187-202, 1983.

Solana, C., Kilburn, C. R. J. Rodriguez Badiola, E., and Aparicio, A.: Fast emplacement of extensive pahoehoe fow-fields: the case of the 1736 flows from Montanña de las Nueces, Lanzarote, J. Volcanol. Geoth. Res., 132, 189-207, 2004.

Thordarson, Th. and Self, S.: The Laki (Skaftar Fires) and Grimsvotn eruptions in 1783-1785, B. Volcanol., 55, 233-263, 1993.

Toyos, G. P., Cole, P. D., Felpeto, A., and Martí, J.: A GIS-based methodology for hazard mapping of small pyroclastic density currents, Nat. Hazards, 41, 99-112, 2007. 